ISSN 0206-5657. Вісник Львівського університету. Серія біологічна. 2019 Випуск 80. С. 146-153 Visnyk of the Lviv University. Series Biology. 2019. Issue 80. P. 146-153

\title{
ЗООЛОГІЯ
}

UDC 595.799:591.9](477.83)

https://doi.org/10.30970/vlubs.2019.80.15

\section{A PRELIMINARY LIST OF BEE SPECIES (HYMENOPTERA, APOIDEA) ON THE TERRITORY OF ROZTOCHYA NATURE RESERVE (UKRAINE)}

\author{
I. Tymkiv ${ }^{*}$, S. Pytel ${ }^{1}$, G. Stryamets ${ }^{2}$ \\ ${ }^{1}$ Ivan Franko National University of Lviv \\ 4, Hrushevskyi St., Lviv 79005, Ukraine \\ ${ }^{2}$ Roztochya Nature Reserve \\ 7, Sichovykh Striltsiv St., Ivano-Frankove, Lviv region 81070, Ukraine \\ e-mail:irynatymkiv93@gmail.com
}

This paper presents a brief overview of bee species that occur on the territory of Roztochya Nature Reserve (mainly, the deciduous forest not far from the fish-breeding ponds near the Ivano-Frankove town and Zalyvky tract - forested area of the sphagnum bog) and its buffer zone (the territory around the fish-breeding pounds and the deciduous forest near the Lelekhivka village). Materials were collected during the vegetation period of 2015-2018. Also, we analyzed the entomological collection of the Zoological Museum of Lviv National University. During this research we collected 60 specimens of bees, which belong to 39 species, 16 genera (Andrena, Anthophora, Apis, Bombus, Nomada, Tetralonia, Colletes, Hylaeus, Lasioglossum, Sphecodes, Systropha, Chelostoma, Megachile, Osmia, Dasypoda, Macropis) and 6 families (Andrenidae - 10 species, Apidae - 15 species, Colletidae -2 species, Halictidae -6 species, Megachilidae -4 species and Melittidae -2 species). 28 of these species are first recorded for the fauna of Roztochya Nature Reserve. Also thirteen species from family Apidae (genus Bombus) were listed in the fauna of Roztochya Nature Reserve earlier by Iryna Konovalova [17], but we didn't collect them during our research. So, in general, a preliminary list of bee species on this territory includes 52 species of insects (including literature data and specimens from the entomological collection of the Museum). 42 species are listed in the "European Red List of bees" [10] in the category "Least Concern", six species - in the category "Data Deficient", two species - in the category "Vulnerable" (Bombus muscorum (Linnaeus, 1758) and Bombus distinguendus Morawitz, 1869) and two species - in the category "Near Threatened" (Andrena ovatula (Kirby, 1802) and Systropha curvicornis (Scopoli, 1770)). One species has a conservation status "Rare" in the Red Data Book of Ukraine (Bombus muscorum (Linnaeus, 1758)) [16]. Such research should be continued and deepened in the nearest future.

Collected specimens are housed at the Zoological Museum of Lviv National University collection (ZMD).

Keywords: bees, Apoidea, Hymenoptera, Roztochya Nature Reserve, Ukraine

Bees are one of the most important pollinators of many kinds of bushes, small trees, and herbaceous plants, including many wild flowers and cultivated plants. Conservation of many habitats thus depends upon preservation of bee populations, for if the bees disappear, reproduction of major elements of the flora may be severely limited [9].

Roztochya Nature Reserve is a part of the same physical and geographic area. Roztochya is a hilly ridge with a height difference of 203-403 meters above sea leveland is located on the main European watershed. Natural complexes of Roztochya were formed under influence of adjacent botanic-geographical regions - Polissya, Podillya and Carpathians. A neibourhood of floristically different regions gave rise to species in the region which are on the edge of their

(C) Тимків І., Питель С., Стрямець Г., 2019 
I. Тимків, С. Питель, Г. Стрямець

natural distribution or to those species located in a separate fragment of an area under disjuction distribution.

\section{Objects and Methods}

The objects of our research were bees (Hymenoptera, Apoidea) that occur on the territory of Roztochya Nature Reserve and its buffer zone. We collected insects during warm period of 2015-2018. Also, we analyzed the entomological collection of the ZMD.

For bee identification we have used few different keys to species $[1-8,11-15,18]$ and the classification of bees follows Ch. D. Michener [9]. Information about IUCN Red List Categories from "European Red List of bees" [10].

Localities of the research

The part of the territory of the Roztochya Nature Reserve: the deciduous forest not far from the fish-breeding ponds near the Ivano-Frankove town; Zalyvky tract - forested area of the sphagnum bog.

Buffer zone of the Reserve: the territory around the fish-breeding pounds and the deciduous forest near the Lelekhivka village.

\section{Results and Discussion}

During our research we collected 60 specimens of bees which belong to 39 species, 16 genera and 6 families (Apidae, Andrenidae, Colletidae, Halictidae, Megachilidae and Melittidae). 28 of these species are first recorded for the Roztochya Nature Reserve.

\section{Family Andrenidae}

1. Andrena barbilabris (Kirby, 1802).

Material examined: outskirts of the Lelekhivka village: $1 \delta$, IV.2017. Distribution: Holarctic. Remarks: IUCN Red List Category - Data Deficient (DD); this is the first record of the species for the RNR.

\section{Andrena bicolor Fabricius, 1775.}

Material examined: outskirts of the Lelekhivka village: 1 ㅇ, $I V .2017$. Distribution: Holarctic. Remarks: IUCN Red List Category - Least Concern (LC); first recorded.

3. Andrena dorsata (Kirby, 1802).

Material examined: outskirts of the Lelekhivka village: 1 ㅇ, IV.2017. Distribution: Palearctic. Remarks: IUCN Red List Category - Data Deficient (DD); first recorded.

\section{Andrena haemorrhoa (Fabricius, 1781).}

Material examined: outskirts of the Ivano-Frankove town (near the ponds): 1 ,, VI.2016; outskirts of the Lelekhivka village: $1 \delta^{\lambda}, I V .2017$. Distribution: Palearctic. Remarks: IUCN Red List Category - Least Concern (LC); first recorded.

\section{Andrena helvola (Linnaeus, 1758).}

Material examined: outskirts of the Lelekhivka village: 1 ,, VI.2017. Distribution: Palearctic. Remarks: IUCN Red List Category - Data Deficient (DD); first recorded.

\section{Andrena lepida Schenck, 1861.}

Material examined: outskirts of the Lelekhivka village: 1ㅇ, VII.2016. Distribution: Palearctic. Remarks: IUCN Red List Category - Data Deficient (DD); first recorded.

\section{Andrena nitida (Müller, 1776).}

Material examined: outskirts of the Ivano-Frankove town (near the ponds): $1 \hat{\delta}, V .2018$. Distribution: Palearctic. Remarks: IUCN Red List Category - Least Concern (LC); first recorded.

\section{Andrena nycthemera Imhoff, 1868.}

Material examined: outskirts of the Lelekhivka village: $1 \stackrel{+}{\circ} 1 \hat{\delta}, I V .2017$. Distribution: Palearctic. Remarks: IUCN Red List Category - Data Deficient (DD); first recorded. 
9. Andrena ovatula (Kirby, 1802).

Material examined: outskirts of the Lelekhivka village: 2 , VII.2016. Distribution:

Palearctic. Remarks: IUCN Red List Category - Near Threatened (NT); first recorded.

10. Andrena vaga Panzer, 1799.

Material examined: outskirts of the Lelekhivka village: $29,1 \hat{\jmath}, I V .2017$. Distribution: Palearctic. Remarks: IUCN Red List Category - Least Concern (LC); first recorded.

\section{Family Apidae}

11. Anthophora plumipes (Pallas, 1772).

Material examined: outskirts of the Lelekhivka village: 2 , VII.2017; outskirts of the Ivano-Frankove town (near the ponds): 1 त $I V .2018$. Distribution: Palearctic (was introduced to the United States also). Remarks: IUCN Red List Category - Least Concern (LC); first recorded.

12. Apis mellifera Linnaeus, 1758.

Material examined: numerous species in all areas of the RNR. Distribution: Palearctic. Remarks: IUCN Red List Category - Data Deficient (DD); species was recorded in the RNR by Reserve staff.

13. Bombus hortorum (Linnaeus, 1761).

Material examined: outskirts of the Lelekhivka village: $2 \not q, V I .2017 ; 2 \hat{\jmath}$, VIII.2017. Distribution: Palearctic. Remarks: IUCN Red List Category - Least Concern (LC); species was recorded in the RNR formerly by I. Konovalova [17].

14. Bombus hypnorum (Linnaeus, 1758).

Material examined: outskirts of the Stradch village: $2 \not$, VI.2017; outskirts of the IvanoFrankove town (near the ponds): 1ф, V.2018. Distribution: Palearctic. Remarks: IUCN Red List Category - Least Concern (LC); species was recorded in the RNR formerly by I. Konovalova [17].

15. Bombus lapidarius (Linnaeus, 1758).

Material examined: numerous species in all areas of the RNR. Distribution: Palearctic. Remarks: IUCN Red List Category - Least Concern (LC); species was recorded in the RNR formerly by I. Konovalova [17].

16. Bombus lucorum (Linnaeus, 1761).

Material examined: numerous species in all areas of the RNR. Distribution: Palearctic, Oriental, Arctic and western Nearctic regions. Remarks: IUCN Red List Category - Least Concern (LC); species was recorded in the RNR formerly by I. Konovalova [17].

\section{Bombus muscorum (Linnaeus, 1758).}

Material examined: outskirts of the Ivano-Frankove town (Stradch forestry): 1ф, VII.2004; Zalyvky tract: 2 , V.2016; outskirts of the Lelekhivka village: $1 \not$, VII.2018. Dis- tribution: Palearctic. Remarks: IUCN Red List Category - Vulnerable (VU); conservation status in the Red Data Book of Ukraine - "Rare" [16]; species was recorded in the RNR formerly by I. Konovalova [17].

18. Bombus pascuorum (Scopoli, 1763).

Material examined: numerous species in all areas of the RNR. Distribution: Palearctic. Remarks: IUCN Red List Category - Least Concern (LC); species was recorded in the RNR formerly by I. Konovalova [17].

19. Bombus pratorum (Linnaeus, 1761).

Material examined: outskirts of the Ivano-Frankove town: 1 , VI.2016; outskirts of the Lelekhivka village: $1 \delta^{\lambda}, I V .2017$. Distribution: Palearctic. Remarks: IUCN Red List Category Least Concern (LC); species was recorded in the RNR formerly by I. Konovalova [17]. 
20. Bombus ruderarius (Müller, 1776).

Material examined: numerous species in all areas of the RNR. Distribution: Palearctic. Remarks: IUCN Red List Category - Least Concern (LC); species was recorded in the RNR formerly by I. Konovalova [17].

21. Bombus sylvarum (Linnaeus, 1761).

Material examined: numerous species in all areas of the RNR. Distribution: Palearctic. Remarks: IUCN Red List Category - Least Concern (LC); species was recorded in the RNR formerly by I. Konovalova [17].

22. Bombus terrestris (Linnaeus, 1758).

Material examined: numerous species in all areas of the RNR. Distribution: Palearctic; was introduced to Australasia, New Zealand and South America. Remarks: IUCN Red List Category - Least Concern (LC); species was recorded in the RNR formerly by I. Konovalova [17].

23. Nomada lathburiana (Kirby, 1802).

Material examined: outskirts of the Ivano-Frankove town (near the ponds): 1 , $I V .2018$. Distribution: Palearctic. Remarks: IUCN Red List Category - Least Concern (LC); first recorded.

24. Nomada zonata Panzer, 1798.

Material examined: outskirts of the Ivano-Frankove town (near the ponds): 1 ㅇ, $I V .2018$. Distribution: Palearctic. Remarks: IUCN Red List Category - Least Concern (LC); first recorded.

25. Tetralonia malvae (Rossi, 1790).

Material examined: outskirts of the Lelekhivka village: 1ㅇ, VII.2016. Distribution: Palearctic. Remarks: IUCN Red List Category - Least Concern (LC); first recorded.

\section{Family Colletidae}

26. Colletes cunicularius (Linnaeus, 1761).

Material examined: outskirts of the Lelekhivka village: $2+$, IV.2017; outskirts of the Ivano-Frankove town (near the ponds): $2 \circ, 2 \hat{O}, I V .2018$. Distribution: Palearctic. Remarks: IUCN Red List Category - Least Concern (LC); first recorded.

\section{Hylaeus confusus Nylander, 1852.}

Material examined: outskirts of the Ivano-Frankove town (near the ponds): $2 \hat{O}$, VI.2016. Distribution: Palearctic. Remarks: IUCN Red List Category - Least Concern (LC); first recorded.

\section{Family Halictidae}

\section{Lasioglossum albipes (Fabricius, 1781).}

Material examined: outskirts of the Ivano-Frankove town (near the ponds): 2 ,, V.2018. Distribution: Palearctic. Remarks: IUCN Red List Category - Least Concern (LC); first recorded.

29. Lasioglossum (Evylaeus) politum (Schenck, 1853).

Material examined: outskirts of the Ivano-Frankove town (on the edge of the forest): 1 , IX.2017. Distribution: Palearctic. Remarks: IUCN Red List Category - Least Concern (LC); first recorded.

30. Lasioglossum zonulum (Smith, 1848).

Material examined: outskirts of the Ivano-Frankove town (near the ponds): 1 ,, VII.2016. Distribution: Holarctic. Remarks: IUCN Red List Category - Least Concern (LC); first recorded.

31. Sphecodes albilabris (Fabricius, 1793).

Material examined: outskirts of the Ivano-Frankove town (near the ponds): 1 으, IV.2016. Distribution: Palearctic. Remarks: IUCN Red List Category - Least Concern (LC); first recorded.

32. Sphecodes monilicornis (Kirby, 1802).

Material examined: outskirts of the Ivano-Frankove town (near the ponds): 1 ㅇ, IV.2016. Distribution: Palearctic. Remarks: IUCN Red List Category - Least Concern (LC); first recorded. 
33. Systropha curvicornis (Scopoli, 1770).

Material examined: outskirts of the Lelekhivka village: 2 , $2 \hat{\sigma}$, VII.2017. Distribution:

Palearctic. Remarks: IUCN Red List Category - Near Threatened (NT); first recorded.

Family Megachilidae

34. Chelostoma florisomne (Linnaeus,1758).

Material examined: outskirts of the Ivano-Frankove town (near the ponds): $1 \hat{O}$, V.2018. Distribution: Palearctic. Remarks: IUCN Red List Category - Least Concern (LC); first recorded.

35. Megachile centuncularis (Linnaeus, 1758).

Material examined: outskirts of the Lelekhivka village: 1 ㅇ, VII.2016. Distribution: Holarctic. Remarks: IUCN Red List Category - Least Concern (LC); first recorded.

36. Megachile circumcincta (Kirby, 1802).

Material examined: outskirts of the Ivano-Frankove town (on the edge of the forest): 1 , , VI.2016. Distribution: Palearctic. Remarks: IUCN Red List Category - Least Concern (LC); first recorded.

37. Osmia bicornis (Linnaeus, 1758).

Material examined: outskirts of the Lelekhivka village: $1 \delta, I V .2017$. Distribution: Palearctic. Remarks: IUCN Red List Category - Least Concern (LC); first recorded.

\section{Family Melittidae}

38. Dasypoda hirtipes (Fabricius, 1793).

Material examined: outskirts of the Lelekhivka village: 1§, VII.2017; outskirts of the Ivano-Frankove town (near the ponds): 1ڤ̂, VIII.2017. Distribution: Palearctic. Remarks: IUCN Red List Category - Least Concern (LC); first recorded.

39. Macropis europaea Warncke, 1973.

Material examined: outskirts of the Lelekhivka village: 1 , $3 \hat{\bigcirc}$ VII.2017. Distribution: Palearctic. Remarks: IUCN Red List Category - Least Concern (LC); first recorded.

Thirteen species from family Apidae were listed in the fauna of RNR earlier by I. Konovalova [17], but we didn't collect them during our research:

1. Bombus barbutellus (Kirby, 1802). Distribution: Palearctic. Remarks: IUCN Red List Category - Least Concern (LC).

2. Bombus bohemicus (Seidl, 1837). Distribution: Palearctic. Remarks: IUCN Red List Category - Least Concern (LC).

3. Bombus campestris (Panzer, 1801). Distribution: Palearctic. Remarks: IUCN Red List Category - Least Concern (LC).

4. Bombus distinguendus Morawitz, 1869. Distribution: Palearctic. Remarks: IUCN Red List Category - Vulnerable (VU).

5. Bombus jonellus (Kirby, 1802). Distribution: Holarctic. Remarks: IUCN Red List Category - Least Concern (LC).

6. Bombus norvegicus Sparre-Schneider, 1918. Distribution: Palearctic. Remarks: IUCN Red List Category - Least Concern (LC).

7. Bombus rupestris (Fabricius, 1793). Distribution: Palearctic. Remarks: IUCN Red List Category - Least Concern (LC).

8. Bombus semenoviellus Skorikov, 1910. Distribution: Palearctic. Remarks: IUCN Red List Category - Least Concern (LC).

9. Bombus soroeensis (Fabricius, 1777). Distribution: Palearctic. Remarks: IUCN Red List Category - Least Concern (LC).

10. Bombus subterraneus (Linnaeus, 1758). Distribution: Palearctic (it has been introduced to New Zealand). Remarks: IUCN Red List Category - Least Concern (LC). 
11. Bombus sylvestris (Le Peletier, 1832). Distribution: Palearctic. Remarks: IUCN Red List Category - Least Concern (LC).

12. Bombus vestalis Geoffroy, 1785. Distribution: Palearctic. Remarks: IUCN Red List Category - Least Concern (LC).

13. Bombus veteranus (Fabricius, 1793). Distribution: Palearctic. Remarks: IUCN Red List Category - Least Concern (LC).

The analysis of our collection of bees, the entomological collection of the Zoological Museum of Lviv National University and the literature data enables to draw a preliminary conclusion about the species composition of the bee fauna of the Roztochya Nature Reserve. In general, a preliminary list of bee species (Hymenoptera, Apoidea) on the territory of Roztochya Nature Reserve includes 52 species, 28 of which are first recorded for the RNR (39 species, collected during our research and 13 species that were listed in the fauna of RNR earlier, but we didn't collect them). 42 species are listed in the "European Red List of bees" [10] in the category "Least Concern", 6 species - in the category "Data Deficient", 2 species - in the category "Vulnerable" and 2 species - in the category "Near Threatened". One species has a conservation status "Rare" in the Red Data Book of Ukraine [16].

Such research should be continued and deepened in the nearest future.

We express the deepest thanks to Mykola Skyrpan for the help with the collection of materials.

\section{REFERENCES}

1. Banaszak J., Romasenko L., Cierzniak T. The identification keys of Poland insects. Hymenoptera, Apoidea - Apidae, subfamily: Megachilinae. Vol. XXIV. N 68b. Torun, 2001. 156 p.(In Polish) [Banaszak J., Romasenko L., Cierzniak T. Klucze do oznaczania Owadów Polski. Hymenoptera, Pszczołowate - Apidae, Podrodzina: Megachilinae. Część XXIV, Zeszyt 68b. Torun, 2001. 156 s.]

2. Celary $W$. Melittidae of Poland (Hymenoptera: Apoidea: Anthophila), their Biodiversity and Biology. Kraków: Wydawnictwa Instytutu Systematyki i Ewolucji Zwierząt Press., 2005. $177 \mathrm{p}$.

3. Chorein A. Systematics and chorology of Anthophorini (Hymenoptera: Apidae) from Belgium to Northern France, with an initial analysis of their volatile secretions. Mons: graduation thesis, University of Mons-Hainaut, 2007. 80 p. (in French) [Chorein A. Systématique et chorologie des Anthophorini (Hymenoptera: Apidae) de Belgique et du Nord de la France, avec une première analyse de leurs sécrétions volatiles. Mons: Mémoire de fin d'études, Université de Mons-Hainaut, 2007. 80 p.]

4. Dylewska M. The identification keys of Poland insects. Hymenoptera, Apoidea - Apidae, subfamily: Andreninae. Vol. XXIV. N 68d. Torun, 2000. 153 p. (in Polish) [Dylewska M. Klucze do oznaczania Owadów Polski. Hymenoptera, Pszczołowate - Apidae Podrodzina: Andreninae. Część XXIV, Zeszyt 68d. Torun, 2000. 153 s.]

5. Hylaeus Test Key: April 2007 (Alan Stubbs) (internet resource: http://www.bwars.com/sites/ www.bwars.com/files/diary_downloads/hylaeus-test-key_stubbs_2007.pdf)

6. Hymenoptera of the world: an identification guide to families / Ed. by Henri Goulet, John T. Huber. Ottawa, Ontario, 1993. 670 p.

7. Løken A. Studies on Scandinavian Bumble Bees (Hymenoptera, Apidae) // Norsk Entomologisk Tidsskrift. 1973. N 20. P. 1-218.

8. Løken A. Scandinavian species of the genus Psithyrus Lepeletier (Hymenoptera: Apidae) // Entomologica scandinavica. 1984. N 20. P. 1-25. 
9. Michener C. D. The Bees of the World. Second edition. Baltimore: J. Hopkins Univ. Press., 2007. 992 p. (ISBN-13: 978-0-8018-8573-0)

10. Nieto A., Roberts S. P. M., Kemp J. et al. European Red List of bees. Luxembourg: Publication Office of the European Union, 2014. 86 p. ISBN: 978-92-79-44512-5

11. Osytshnjuk H. Z. Fauna of Ukraine. Vol. 12. Apoidea. N 4. Colletidae. Kyiv: Naukova Dumka, 1970. 160 p. (In Ukrainian) [Осичнюк Г.З. Фауна України. Т. 12. Бджолині. Вип. 4. Бджоли-колетиди. К.: Наукова думка, 1970. 160 с.]

12. Osytshnjuk H. Z. Fauna of Ukraine. Vol. 12. Apoidea. № 5. Andrenidae. Kyiv: Naukova Dumka, 1977. 328 p. (In Ukrainian) [Осичнюк Г.З. Фауна України. Т. 12. Бджолині. Вип. 5. Бджоли-андреніди. К.: Наукова думка, 1977. 328 с.]

13. Pesenko Yu. A., Banaszak J., Radchenko V. G., Cierzniak T. Bees of the family Halictidae (excluding Sphecodes) of Poland: taxonomy, ecology, bionomics. Bydgoszcz, 2000. 348 p. ISBN 83-7096-339-0.

14. Pesenko Yu. A., Banaszak J., Cierzniak T. The identification keys of Poland insects. Hymenoptera, Apoidea - Apidae, subfamily: Halictinae Vol. XXIV, № 68b. Torun, 2002. 111 p. (In Polish) [Pesenko Yu. A., Banaszak J., Cierzniak T. Klucze do oznaczania Owadów Polski. Hymenoptera, Pszczołowate - Apidae, Podrodzina - Halictinae. Część XXIV, Zeszyt 68b. Torun, 2002. $111 \mathrm{~s}$.].

15. Proshchalykin M. Yu., Kuhlmann M. The bees of the genus Colletes Latreille 1802 of the Ukraine, with a key to species (Hymenoptera: Apoidea: Colletidae) // Zootaxa. 2012. Vol. 3488. P. 1-40.

16. Red Data Book of Ukraine. Animals / Ed. by I. A. Akimov. Kyiv: Globalconsalting, 2009. 600 p. ISBN 978-966-97059-0-7 (In Ukrainian) [Червона книга України. Тваринний світ / за ред. І.А. Акімова. К.: Глобалконсалтинг, 2009. 600 с. ISBN 978-966-97059-0-7].

17. Rizun V., Heryak Yu., Hirna A. et al. Arthropods of the Roztochya Nature Reserve. Lviv, 2010. 395 p. ISBN 978-966-02-5817-4 (In Ukrainian) [Різун В., Геряк Ю., Гірна А. та ін. Членистоногі природного заповідника “Розточчя". Львів, 2010. 395 с. ISBN 978-96602-5817-4].

18. Smit $J$. The Wasp Bees (Nomada) of the Netherlands (Hymenoptera: Apidae) // Dutch Faunist Announcements. 2004. N 20. P. 33-126 (In Dutch) [Smit J. De wespbijen (Nomada) van Nederland (Hymenoptera: Apidae) // Nederlandse Faunistische Mededelingen. 2004. N 20. P. 33-126]. 
І. Тимків, С. Питель, Г. Стрямець

\title{
ПОПЕРЕДНІЙ СПИСОК БДЖОЛИНИХ (НYМЕNОРТЕRА, АРОIDЕА) ПРИРОДНОГО ЗАПОВІДНИКА “РОЗТОЧЧЯ” (УКРӒ̈НА)
}

\author{
${\text { I. } \text { Тимків }^{1 *} \text {, С. Питель }}^{1}$, Г. Стрямець ${ }^{2}$ \\ ${ }^{1}$ Львівський національний університет імені Івана Франка \\ вул. Грушевського, 4, Львів 79005, Україна \\ ${ }^{2}$ Природний заповідник "Розточчя" \\ вул. Січових Стрільичв, 7, Івано-Франкове, Львівська обл. 81070, Украӥна \\ e-mail: irynatymkiv93@gmail.com
}

У публікації подано короткий огляд видів бджолиних, зібраних на території природного заповідника "Розточчя" (переважно мішаний ліс недалеко від риборозплідних ставів на околицях смт Івано-Франкове й урочище Заливки - заліснена ділянка сфагнового болота) і його буферної зони (територія навколо риборозплідних ставів та мішаний ліс на околицях с. Лелехівка). Матеріал збирали протягом вегетаційного періоду 2015-2018 років. Також аналізували ентомологічні колекції Зоологічного музею. Упродовж досліджень зібрали 60 екземплярів бджолиних, котрі належать до 39 видів, 16 родів (Andrena, Anthophora, Apis, Bombus, Nomada, Tetralonia, Colletes, Hylaeus, Lasioglossum, Sphecodes, Systropha, Chelostoma, Megachile, Osmia, Dasypoda, Macropis) і 6 родин (Andrenidae - 10 видів, Apidae - 15 видів, Colletidae - 2 види, Halictidae -6 видів, Megachilidae - 4 види та Melittidae -2 види). Із них -28 видів зареєстровані для заповідника вперше. Ще 13 видів із родини Apidae (рід Bombus) були зареєстровані для фауни заповідника раніше I. Коноваловою [17], проте у наших зборах вони не траплялися. Тож загальний попередній список бджолиних на території природного заповідника "Розточчя" включає 52 види (враховуючи також літературні дані й екземпляри 3 ентомологічної колекції Музею). 42 види комах числяться в “Свропейському червоному списку бджіл” [10] у категорії "Least Concern” (“Найменший ризик”), шість видів - у категорії "Data Deficient” (“Недостатньо інформації”, два види - в категорії "Вразливі" ("Vulnerable”) (Bombus muscorum (Linnaeus, 1758) i Bombus distinguendus Morawitz, 1869) і два види - в категорії “Близькі до загрозливого стану" ("Near Threatened") (Andrena ovatula (Kirby,1802) та Systropha curvicornis (Scopoli, 1770)). Один вид (Bombus muscorum (Linnaeus, 1758) занесений до Червоної книги України під статусом “Рідкісний” [16]. Такі дослідження будуть продовжені та поглиблені у майбутньому.

Зібраний матеріал зберігається у Зоологічному музеї Львівського національного університету імені Івана Франка (ЗМД).

Ключові слова: бджолині, Apoidea, Hymenoptera, природний заповідник “Розточчя”, Україна 